\title{
Implementation process of the strategy of surveillance of chronic musculoskeletal pain in basic health care. Case report
}

\author{
Processo de implantação da estratégia vigilância à dor crônica osteomioarticular na atenção básica. \\ Relato de caso
}

Francisco Ednardo Damasceno Silva ${ }^{1}$, Francisco Rafael Pinheiro Dantas², Raimunda Hermelinda Maia Macena ${ }^{3}$, Thiago Brasileiro de Vasconcelos ${ }^{3}$

DOI 10.5935/1806-0013.20160017

\section{ABSTRACT}

BACKGROUND AND OBJECTIVES: Chronic pain is a persistent indicator for the basic health care. It is estimated that between 30 and $40 \%$ of Brazilians suffer some chronic pain, including musculoskeletal pain, making necessary the development of strategies to cope with such indicator. In light of the above, this study aimed at reporting the experience of the implementation process of the Strategy of Surveillance of Chronic Musculoskeletal Pain in basic health care of the city of Maracanaú/CE.

METHODS: This is a qualitative and interpretative study by means of description of the strategy implementation process stages.

RESULTS: The Strategy of Surveillance of Chronic Musculoskeletal Pain flowchart was based on and made up of an open cycle, where patients admitted to the unit with musculoskeletal pain were submitted to initial evaluation by the nursing team, and then were referred to the physician for clinical consultation and diagnosis of referred pain. In case of chronic musculoskeletal pain, patients were referred to physiotherapy.

CONCLUSION: The implementation of the strategy has allowed for more systematic integration among Family Health Strategy professionals. For physiotherapists, the experience has brought further guidance as to the actions of the category in basic health care with regard to prevention, promotion and health education.

Keywords: Chronic pain, Integrality in health, Physiotherapy, Primary health care.

1. Escola de Saúde Pública do Ceará, Fortaleza, CE, Brasil.

2. Prefeitura Municipal de Maracanaú, Fortaleza, CE, Brasil.

3. Universidade Federal do Ceará, Fortaleza, CE, Brasil.

Submitted in July 22, 2015.

Accepted for publication in December 21, 2015.

Conflict of interests: none - Sponsoring sources: none.

Correspondence to

Thiago Brasileiro de Vasconcelos

Rua: Aveledo, 501/201, Torre 2 - Messejana

60871-210 Fortaleza, CE, Brasil.

E-mail: thiagobvasconcelos@hotmail.com

(C) Sociedade Brasileira para o Estudo da Dor

\section{RESUMO}

JUSTIFICATIVA E OBJETIVOS: A dor crônica é um indicador persistente na atenção básica de saúde. Estima-se que entre $30 \mathrm{e}$ $40 \%$ dos brasileiros estejam acometidos por alguma dor crônica, incluindo a dor de origem osteomioarticular, tornando necessárias estratégias para enfrentamento de tal indicador. Em vista disso, objetivou-se relatar a experiência do processo de implantação da Estratégia Vigilância à Dor Crônica de Origem Osteomioarticular na atenção básica no município de Maracanaú/CE.

MÉTODOS: Trata-se de um estudo que aborda a experiência de abordagem qualitativa, interpretativa por meio da descrição das fases do processo de implantação da estratégia.

RESULTADOS: O fluxograma da Estratégia Vigilância à Dor Crônica Osteomioarticular foi fundamentado e constituído por um ciclo aberto, onde o paciente admitido na unidade com queixas de dores osteomioarticulares submetia-se à avaliação inicial da enfermagem, e posteriormente, era encaminhado ao médico para consulta clínica e diagnóstico da referida dor. Caso diagnosticado com dor crônica de origem osteomioarticular, o paciente era encaminhado para fisioterapia.

CONCLUSÃO: A implantação da estratégia possibilitou pactuações mais sistemáticas de integração entre os profissionais da Estratégia Saúde da Família. Para a fisioterapia, a experiência possibilitou maiores esclarecimentos quanto à atuação da categoria na atenção básica em vista da prevenção, promoção e educação em saúde.

Descritores: Atenção primária à saúde, Dor crônica, Fisioterapia, Integralidade em saúde.

\section{INTRODUCTION}

Health surveillance is defined as healthcare model characterized by different types of actions aimed at controlling risks and injuries to the health of populations living in territories, in the context of healthcare integrality, which leads to include both individual and collective approaches to health problems ${ }^{1}$. In this sense, several health indicators in basic healthcare require the development of strategies and actions to cope with them, however they should be planned and thought in the context of health integration and surveillance.

A good example is the chronic musculoskeletal pain indicator, because it is estimated that 7 to $40 \%$ of the world population have chronic pain in different body sites, including pain of this 
origin $^{2,3}$, the causes of which vary according to lifestyle, financial conditions and emotional factors, among others ${ }^{4}$.

Musculoskeletal disorders are in general caused by structural and functional disorders, which in general peak with progressive and severe pain 5 .

Chronic musculoskeletal pain (CMP) may have noxious consequences for quality of life. Factors such as depression, temporary or permanent physical and functional incapacity, dependence, frequent absences to work, social isolation, difficulties with sexual activities, changes in family dynamics, economic imbalance, hopelessness, feeling of death and others are associated to $\mathrm{CMP}^{6}$, being considered a severe problem for workers' health.

In light of the above and of the experience with the Single Health System (SUS) by means of Integrated Residence on Health (RIS), we have observed the high demand of patients admitted to Basic Family Health Units (UBASF) with chronic musculoskeletal pain; however, in most cases, proposed procedures have not reached results expected by the multidisciplinary team and by the users, added to the lack of integration between the Family Health Team (EqSF) and the Family Health Support Nucleus (NASF) within this health situation.

So, due to this health situation and the working processes of teams when coping with such indicator, there has been the need to implement the Strategy Chronic Musculoskeletal Pain Surveillance (EVDCO), with direct physiotherapeutic actions throughout the process. This study aimed at reporting the experience of EVDCO implementation process in the basic healthcare of the city of Maracanaú/CE.

\section{EXPERIENCE REPORT}

This is a study addressing the experience of Physiotherapy practice integrated to Integrated Residence on Health by the Escola de Saúde Pública do Ceará (RIS-ESP/CE), and emphasizing Family and Community Health, with qualitative and interpretative approach, through the description of EVDCO planning, implementation and execution phases aiming at promoting health and preventing and controlling CMP.

Strategy was implemented during May and June 2014. Assumptions of Teixeira ${ }^{1}$ and $\mathrm{Codo}^{7}$ were applied to guide the pathway between theory and practice of management and articulation process to implement the strategy.

Physiotherapists were EVDCO protagonists, however the whole process has involved different professionals of UBASF Irmã Maria Heleny Matos Brandão (Maracanaú/CE). A total of 10 professionals have participated in the implementation: one physician, two nurses (being one resident nurse), two physiotherapists (being one resident and one preceptor of the physiotherapy center) and five Community Health Agents (ACS).

Aiming at developing, planning, establishing goals, deadlines and strategic objectives of the health situation indicator, CMP, the implementation process of the strategy has gone through the following stages:

$1^{\text {st }}$ Stage - Health situation room: Moments of inverted tent as nucleus teaching activity ${ }^{8}$ of the RIS-ESP/CE program were used for the holding of health situation rooms ${ }^{9,10}$ related to physiotherapy demands, moments in which problems were presented by physiotherapists (preceptor and residents) with regard to chronic mus- culoskeletal pain, with articulations, ideas, hypotheses and service reviews for then reaching a consensus as to the need for planning to implement a strategy, which was called: Chronic Musculoskeletal Pain Surveillance.

$2^{\text {nd }}$ Stage - Design of the strategy: Stage aimed at planning all strategy stages and pathways, to obtain a well structured and sound implementation. Major strategy designs were: strategy flowchart, tools that were used (materials for data collection and clinical evaluation) and also existing and active devices in the territory to act as support to the applicability and maintenance of the strategy (active health promotion groups in the territory - Functional Group, Elderly Group, Wellbeing Group).

$3^{\text {rd }}$ Stage - Demonstration: Team meetings to strengthen the strategy among professionals of the unit (physician, nurses and ACS), by explaining EVDCO objectives and goals, the profile of users to be recruited and referred to it, in addition to medical visits scheduling. $4^{\text {th }}$ Stage - Formalization of the implementation of the strategy: Considering the potential of team meetings as source for strengthening the planning of strategies and agreement of actions, this media was used to formalize the implementation of EVDCO with the participation of professionals directly involved, of the UBASF Coordinator and of ANVISA Manager 5 .

From July 2014 to March 2015 were forwarded 29 patients for the screening performed by EVDCO, 27 (93.10\%) presented the profile of musculoskeletal chronic pain, followed the flow and they were assessed by the physiotherapist, other 2 patients $(6.90 \%)$ presented profile of acute pain and were not included in the strategy.

The product of the whole EVDCO implementation process was built during the $2^{\text {nd }}$ stage. So, the result of this study was the strategy design itself, which is presented in a simple, clear and objective way through the flowchart (Figure 1), as well as with the detailed

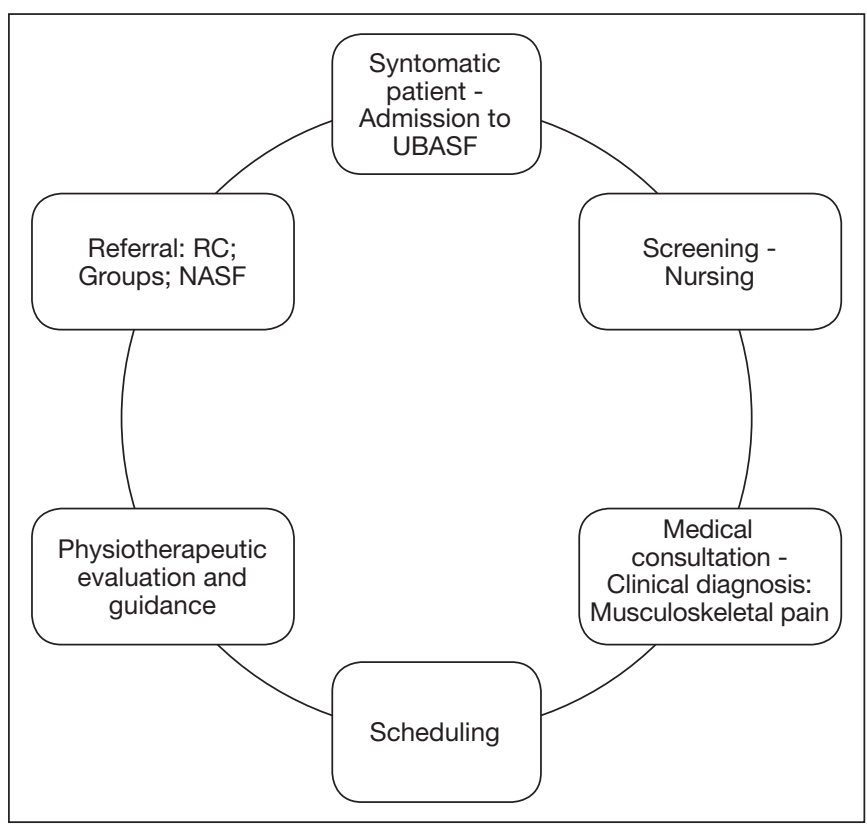

Figure 1. Flowchart of the implementation of the experience process UBASF = Basic Family Health Units; RC = Rehabilitation Center; Groups - Active health promotion groups in the territory; NASF = Family Health Support Nucleus. 
and grounded description of each pathway followed by professionals and users.

EVDCO flowchart was grounded and made up of an open cycle (Figure 1), where patients admitted to the unit with musculoskeletal pain complaints were submitted to nursing evaluation for screening purposes. Then, they were referred to the physician for clinical evaluation and diagnosis of that pain. If diagnosed with chronic musculoskeletal pain, patients were referred to the physiotherapist.

The implementation of the strategy, was as follows:

1) Patients recruited and referred by ACS or free demand patients were admitted to UBASF and were submitted to nursing screening to identify the chronic pain based on the International Association for the Study of Pain (IASP) classification and on most studies about chronic pain, which classify this pain as pain starting and persisting for six months or more ${ }^{4}$.

2) Local unit physician consultation for clinical diagnosis of the injury. Those included by screening shall follow the strategy flow.

3) Following, during physiotherapist consultation, a new screening was performed, aiming at confirming the type of pain. Clinical physiotherapeutic evaluation has followed the protocol below: history, analysis of additional tests, physical evaluation, osteopathic evaluations, specific orthopedic tests, in addition to the application of Barthel Functionality Scale (Barthel Index) ${ }^{11}$ to elderly patients. Evaluation techniques were used according to the need to investigate each case. Next, patients were explained about injury mechanism in simple terms.

4) Afterward, guidance was given about best habits to be adopted, encouragement to the practice of regular physical activities and instructions for the performance of some practical and easy therapeutic methods (cryotherapy, stretching, activefree movements, etc.) to be performed by patients as a way to prevent injury progression and control pain, aiming at better quality of life. Elderly patients were referred to the Healthy Life for the Elderly Group made up of resident professionals (nurse, physiotherapist and psychologist) in the district where UBASF is located.

5) Specific cases needing further attention were referred to rehabilitation centers of the city, to other active health promotion groups or to professionals of other AVISA's NASF categories.

\section{DISCUSSION}

The evaluation of clinical results, interpretation, intuition and experience Professional be used to develop a therapeutic program designed to relieve pain, restore function and preventing their recorrência ${ }^{12}$.

With regard to basic healthcare strategies, it is critical to understand the terms which are pillars for the actions of health promotion, prevention and education, to start coping with different health realities in the territory. These terms are highlighted in the public health universe, such as territorialization, integration, integrality and health surveillance.

Talking of integration, it is important to remind concepts and divisions of this segment which is so targeted and has its applicability demanded by basic healthcare teams. So, it is necessary to distinguish between "integrality" and "integration", which sometimes are used as synonyms with regard to health services organization. The former, in a brief definition, is an attribute of the healthcare model, something that "should be". Integration is a process, is something "to do", so that healthcare models are integral $^{1}$.

The EVDCO as a means to effectively meet community health needs, appreciates integrality and intersectorial actions in healthcare ${ }^{13,14}$, following the health surveillance pathway and supported by three fundamental pillars: territory, problems and practices ${ }^{15}$. Cruz et al. ${ }^{16}$ corroborate with this study, and highlight the importance of identifying losses associated with chronic pain, because it will contribute to the organization proposals to prevent and to reduce these aggravations, and the physiotherapist an indispensable professional to identify the clinical mechanisms of pain through its evaluation, so as to determine an effective method of treatment for pain ${ }^{17-19}$.

Thus, Smart and Doodyb ${ }^{17}$ and Nijs and Van Houdenhove ${ }^{20}$ added the understanding and identification of these mechanisms assist in judgment and clinical reasoning assessment, treatment and prognosis of patients with pain.

The implementation of innovative strategies working with different and frequent indicators, as well as with chronic musculoskeletal pain, aims at establishing the definition of problems and priorities, unifying and organizing promotion and prevention activities, such as assistance-rehabilitating actions ${ }^{21}$. Noting that most of the patients were referred to other services.

Because this is public health in basic healthcare, specifically in family health, it is necessary that the reality of users is understood by professionals who, in addition to identifying indicators, should encourage users with regard to preventive health promotion activities.

According Mongini et al. ${ }^{22}$, a simple home exercise program significantly reduces the pain intensity, the frequency of crises and the monthly intake of drugs for pain control.

This whole territory complexity in its social, economic, cultural and health aspects, leads to the need for health strategic planning to create, develop and carry out actions promoting basic healthcare integration through health promotion, prevention and education. Several claim that the actions must be articulated models representing spaces of participatory practices, autores $^{23-25}$ constructive and targeted for the autonomy of individuals.

Concepts and divisions of terms integration and integrality, described by Teixeira ${ }^{1}$, guide basic healthcare in its strategies and health actions, because they are pillars orienting implementation processes of strategies in this context, as that proposed by EVDCO.

Our study was based on those foundations, constantly considering such pillars, to think, create and plan successful ideas which would become strategies promoting integration, resulting in a product - EVDCO design and flowchart. Such product is linked to health integration and surveillance segments. 


\section{CONCLUSION}

The development of a strategic planning for the implementation process of any kind of strategy is critical for implementation and applicability success. We believe that with this previous practice in face of health strategies it is possible to decrease the possibility of mistakes, to find future obstacles and to reach objectives and goals, be them at the short, medium or long term.

Within the Family Health Strategy scope, it was noticed that the implementation of the Strategy Chronic Musculoskeletal Pain Surveillance has culminated in more systematic possibilities of agreement as to integration of communication among professionals, being identified and agreed by all possibilities of more continuous dialogues formalized by major recording tools, such as the evolution on medical charts, notifications on recording books of $\mathrm{NASF} / \mathrm{EqSF}$ teams, further use of reference and counter-reference materials, in addition to better using work schedules of NASF/ EqSF teams to hold more periodic meetings with them.

For physiotherapy, this successful experience has been challenging, gratifying and enriching, because it has provided further explanations about the action of the category in non-assistance aspect of basic healthcare, by means of activities which give it a more observational, strategist and idealizing view of integration proposals for basic healthcare, as well as the competence to coordinate and lead the whole implementation process of the health surveillance strategy axis, aiming at health prevention, promotion and education.

\section{REFERENCES}

1. Teixeira C. Os Princípios do Sistema Único de Saúde. Texto de Apoio para Subsidiar o Debate nas Conferencias Municipal e Estadual de Saúde. Salvador, Jun 2011. [11 mai 2015] Disponível em: http://www.saude.ba.gov.br/pdf/OS_PRINCIPIOS_DO_ SUS.pdf.

2. Dellaroza MS, Pimenta CA, Matsuo T. [Prevalence and characterization of chronic pain among the elderly living in the community]. Cad Saude Publica. 2007;23(5):115160.Portuguese.

3. Fishbain DA, Lewis JE, Cole B, Cutler RB, Rosomoff HL, Rosomoff RS. Variables associated with current smoking status in chronic pain patients. Pain Med. 2007;8(4):301-11.

4. Sá K, Baptista AF, Matos MA, Lessa I. Prevalence of chronic pain and associated factors in the population of Salvador, Bahia. Rev Saude Publica. 2009;43(4):622-30. English, Portuguese.

5. Meneses GS, Leorne RO, Gouveia SS, Gouveia GP. Correlaçâo das alteraçôes os- teomioarticulares e dor em idosos de Morrinhos (CE). RBCEH, Passo Fundo. 2013;10(2):139-49.

6. Picavet HS, Schouten JS. Musculoskeletal pain in the Netherlands: prevalences, consequences

1. and risk groups, the DMC(3)-study. Pain. 2003;102(1-2):167-78

7. Codo F. Sala de Situaçăo Gerencial Baseada no Planejamento Estratégico Situacional para Gestão Publica. Estratégias Globais e Sistemas Produtivos Brasileiros. IX Work Shop de Pós-Graduação e Pesquisa do Centro Paula Souza. Sáo Paulo 15 e 16 de Outubro de 2014. 127-35p. [11 Mai 2015]. Disponível em: http://www.centropaulasouza.sp.gov.br.

8. Pagani R, Andrade, LO. Preceptoria de território, novas práticas e saberes na estratégia de educação permanente em saúde da família: o estudo do caso de Sobral, CE. Saúde Soc. 2012;21(Suppl1):94-106.

9. Bueno H. Histórico e avanços na utilizaçáo das Salas de Situação em Saúde no Brasil. In: Moya J. et al. (org). Sala de Situação em Saúde: compartilhando as experiências do Brasil. Organizaçáo Pan-Americana da Saúde - Ministério da Saúde, Brasília: 2010. 61-4p.

10. Samico I, Hartz ZM, Felisberto E, Frias PG. A sala de situaçáo da unidade de saúde da família: o Sistema de Informação da Atenção Básica (SIAB) como instrumento para o planejamento estratégico local. Saúde em Debate. 2002;61(26):236-44.

11. Minosso JS, Amendola F, Alvarenga MR, Oliveira MA. Validation of the Barthel Index in elderly patients attended in outpatient clinics, in Brazil. Acta Paul Enferm. 2010;23(2):218-23

12. Franco AL, Zamperini CA, Salata DC, Silva EC, Albino-Junior W, Camparis CM Fisioterapia no tratamento da dor orofacial de pacientes com disfunção temporomandibular crônica. Rev Cubana Estomatol. 2011;48(1):56-61.

13. Moraes DR. Revisitando as concepçóes de integralidade. Rev Atenção Prim Saúde 2006;9(1):64-72.

14. Wimmer GF, Figueiredo GO. Ação coletiva para qualidade de vida: autonomia, transdisciplinaridade e intersetorialidade. Ciênc Saúde Coletiva. 2006;11(1):145-54.

15. Oliveira CM, Casanova AO. Vigilância da saúde no espaço de práticas da atençāo básica. Ciênc Saúde Coletiva. 2009;14(3):929-30.

16. Cruz HM, Pimenta CA, Dellarozza MS, Braga PE, Lebrão ML, Duarte YA. Quedas em idosos com dor crônica: prevalência e fatores associados. Rev Dor. 2011;12(2):10814.

17. Smart K, Doodyb D. Mechanisms-based clinical reasoning of pain by experienced musculoskeletal physiotherapists. Physiotherapy 2006;92(3):171-8.

18. Kumar SP, Saha S. Mechanism-based classification of pain for physical therapy management in palliative care: A Clinical Commentary. Indian J Palliat Care. 2011;17(1):80-6.

19. Gosling AP. Physical therapy action mechanisms and effects on pain management. Rev Dor. 2012;13(1):65-70.

20. Nijs J, Van Houdenhove B. From acute musculoskeletal pain to chronic widespread pain and fibromyalgia: application of pain neurophysiology in manual therapy practice. Man Ther. 2009;14(1):3-12.

21. Bertolozzi MR, Fracolli L. A. Vigilância à saúde: alerta continuado em saúde coletiva. O Mundo da Saúde. 2005;28(1):14-20.

22. Mongini F, Ciccone G, Rota E, Ferrero L, Ugolini A, Evangelista A, et al. Effectiveness of an educational and physical programme in reducing headache, neck and shoulder pain: a work place controlled trial. Cephalalgia. 2008;28:541-52.

23. Marziale MH, Jesus LC. Explanative and intervention models in workers' health promotion. Acta Paul Enferm. 2008;21(4):654-9.

24. Mitre SM, Batista RS, Mendonça JM, Pinto NM, Meirelles CA, et al. Metodologias ativas de ensino-aprendizagem na formaçāo profissional em saúde: debates atuais. Ciênc Saúde Coletiva. 2008;13(Suppl 2):2133-44.

25. Montes de Oca Recio N, Machado RE. Estrategias docentes y métodos de enseñanzaaprendizaje em la Educación Superior. Rev Hum Med. 2011;11(3):475-88. 